University of Nebraska - Lincoln

DigitalCommons@University of Nebraska - Lincoln

Publications from USDA-ARS / UNL Faculty

U.S. Department of Agriculture: Agricultural

Research Service, Lincoln, Nebraska

1993

Biology and Control of Cattle Grubs

Philip J. Scholl

United States Department of Agriculture

Follow this and additional works at: https://digitalcommons.unl.edu/usdaarsfacpub

Part of the Agricultural Science Commons

Scholl, Philip J., "Biology and Control of Cattle Grubs" (1993). Publications from USDA-ARS / UNL Faculty. 1052.

https://digitalcommons.unl.edu/usdaarsfacpub/1052

This Article is brought to you for free and open access by the U.S. Department of Agriculture: Agricultural Research Service, Lincoln, Nebraska at DigitalCommons@University of Nebraska - Lincoln. It has been accepted for inclusion in Publications from USDA-ARS / UNL Faculty by an authorized administrator of DigitalCommons@University of Nebraska - Lincoln. 


\section{BIOLOGY AND CONTROL OF CATTLE GRUBS ${ }^{1}$}

\section{Philip J. Scholl}

Knipling-Bushland U.S. Livestock Insects Research Laboratory, Agricultural Research Service, U.S. Department of Agriculture, Kerrville, Texas 78029

KEY WORDS: Hypoderma lineatum, Hypoderma bovis, heel fly, warble, gadding

\section{PERSPECTIVES AND OVERVIEW}

Two species of cattle grubs (Diptera: Oestridae) affect cattle in the Northern Hemisphere: Hypoderma lineatum, the common cattle grub or lesser cattle warble fly, and Hypoderma bovis, the northern cattle grub or larger cattle warble fly. The word warble is Anglo-Saxon for boil.

Adults of the cattle grub are commonly known as heel flies, warble flies, bomb flies, or gad flies. This parasite has been observed and recorded for centuries (159), and Bracy Clark (50) cited and discussed references from Biblical times to Shakespeare. Scientific observations on the biology were first recorded in the 1700s by Vallisnieri (cited in 224) in Italy, followed by an extensive review and taxonomic description by Brauer (34) in Austria in the mid 19th century. Major contributions followed in England by Ormerod (157) and Imms (93); in the United States by Riley (179), Osborn (158), Bishopp et al (24), and Mote (132); and in Canada by Hadwen (85). Other reviews completed before the widespread use of systemic insecticides for cattle-grub control include work by James (94) and Scharff (185) in the United States, Gansser in Austria (69), Gebauer in Germany (70), Grunin in Russia (81), Natvig in Norway (141), MacDougall in Scotland (124), and Bevan \& Edwards (22) in England. The quality of these reviews makes it unnecessary to repeat detailed information about the stage descriptions and life cycles for these two important species. Rather, I attempt to summarize these contributions, emphasizing additions to our knowledge since the 1950s.

${ }^{1}$ The U.S. Government has the right to retain a nonexclusive royalty-free license in and to any copyright covering this paper. 


\section{BIOLOGY}

\section{Life Cycle and Damage}

Female Hypoderma spp., which are bee-like in appearance (85), use a specialized ovipositor $(75,133)$ to attach their eggs to host animal hairs by means of an attachment organ (51), which is an outgrowth of the egg chorion. The most often selected site of attachment are hairs on the legs and lower body regions of cattle (83). The body temperature of the host animal aids in incubation of the eggs, which is normally 3-7 days (24). Newly hatched larvae ( $\sim 1 \mathrm{~mm}$ in length) (42), crawl to the base of the hair shaft and penetrate the host (43) by means of proteolytic enzymes secreted from their blind midgut $(115,142)$. Occasionally, edema and inflammation occur at the penetration site, most often with older, previously infested animals (73). Once inside the host, the first-stage larvae migrate for 4 to 6 months, normally through the fascial planes between muscles, along connective tissue (86), or along nerve pathways (35), again aided by proteolytic enzymes secreted from the anterior part of the migrating larvae (26). Digestion by the larvae is transcuticular (48); enzyme action aids in the transport of nutrients into the hemolymph. Hypoderma lineatum larvae travel forward to the resting site $(12,17)$ in the loose submucosal connective tissue of the esophagus $(88,199)$. Hypoderma bovis larvae move to a similar resting site in the epidural fat between the dura mater and periosteum in the region of the thoracic and lumbar vertebrae of the spinal canal (220). During the period when larvae accumulate in sizable numbers in their resting sites, treatment with systemic insecticides is contraindicated because of the possibility of adverse reactions due to inflammation from large numbers of grubs being killed in a confined area. Typical symptoms with $H$. lineatum are bloating or vomiting $(101,186)$, and with $H$. bovis, the reaction may be manifested as temporary posterior paralysis $(57,100,134$, 135).

Eventually, the late first-instar larvae ( $\sim 15 \mathrm{~mm}$ in length) of both species leave their respective resting sites, move to the middorsal region of the host (86), and position themselves just under the skin (201). Here they open respiratory holes in the skin and evert with their posterior spiracles toward the breathing pore (70). A cyst then begins to form around each larva. The total migration time of larvae from egg hatch to arrival at the back is 8 to 9 months. The damage done to cattle hides by the presence of large numbers of these pores (149) has been the major economic loss due to Hypoderma infestation $(10,66,92,127,150,222)$.

The cyst-like furuncles, or warbles, are of host origin $(4,84)$. Here the larvae dramatically increase in size (from 15 to $30 \mathrm{~mm}$ ) through two molts for a period of 30 to 60 days. Larvae inside the warbles live in a relatively stable environment (145) of inflammatory exudate (147) and depress second- 
ary infection by production of bacteriostatic substances $(15,95)$. After the mature larvae exit, healing of the skin opening is rapid (126). Carcasses from slaughtered cattle with severe infestations must often be rimmed drastically to remove the jellied fat and meat tissue located beneath the warbles (166, 177).

Immediately prior to exiting the warble, the grubs become distinctly darkened $(97,192)$, and the fully mature larvae exit their warbles through the pores. These still-motile larvae drop to the ground, crawl under leaf litter or burrow near the surface in loose soils $(40,198)$, pupariate $(128)$, and undergo pupal metamorphosis for another 30-90 days, depending on temperature and humidity (164).

The adults (11-18 $\mathrm{mm}$ in length) emerge from the puparium through an operculum and immediately crawl to where their wings can harden and expand. The adults are aphagous $(20,184)$ and must mate and reproduce solely on the energy derived from stored reserves. Their life span is normally 3-5 days, but they can live 10-15 days under laboratory conditions (79). For mating, adults aggregate at sites in steep-banked draws or stream beds (46, 69 ). Hybridization is probably prevented by temporal and spatial separation of the two species, and attempts to produce hybrids by laboratory mating have been unsuccessful (216). The males wait at the sites for females to fly through to copulate (46). Females normally mate only once, although multiple matings are possible (216). The females emerge with a fully developed complement of 300-650 eggs (193), and unlike most other Diptera, they do not require a postfertilization pause to mature their eggs (213). Female Hypoderma spp. have two unique adaptations that help compensate for their short, aphagous life span. The first is the initiation of oogenesis in the late third-instar larvae in the warbles $(25,193)$. The second is the simultaneous development of two oocytes within the same ovariole, thus doubling the reproductive capacity (193).

Following copulation, the females search for a suitable host. Oviposition between the two species also differs. $H$. lineatum normally deposit eggs in long, connected strings, often while the host animal is at rest (44); H. bovis, however, oviposits eggs singly by darting in and attaching each egg on an individual hair shaft (24). The persistent activity and buzzing by the latter species causes cattle to gad, an agitated, instinctive flight response of cattle to the presence of an ovipositing $H$. bovis female $(84,85)$. Injury and miring of fleeing cattle, spontaneous abortion, reduced milk production (178), delayed breeding, and the increased labor necessary to regather stampeded cattle are all potential but, to date, unassessed losses due to gadding (84, 175). The fly has no apparatus to cause pain, either in the form of piercing mouthparts or a sting, so the intensity and cause for this exaggerated response are still not completely understood (146). 
The question of reduction in weight gain attributable to Hypoderma spp. infestation is still open to interpretation. Several studies reported that parasitism by Hypoderma spp. larvae caused marked reduction in weight gain $(83,106,122)$. In determining the total impact of arthropods on livestock production, Drummond et al (65) reported more than $\$ 600$ million annual losses due to cattle grubs in the United States, excluding the cost of control. Drummond (62) later analyzed 26 trials that measured average daily gain and reported that at least half of the trials showed no treatment advantage, and he revised his annual loss figures to $\$ 66$ million, still excluding the cost of control. In a Canadian study, Scholl et al (191) measured the production effects of cattle grubs on beef cattle with no control and found no discernible difference in several beef production values among cattle with 2-39 grubs. Many questions remain unanswered, such as the threshold level of infestation that causes economic loss, interaction with environmental stress, effects of other parasitic infections (especially endoparasites), and the appetite-enhancement effect of some treatments.

\section{Life-Stage Description}

In addition to the review articles above and those citations that give specific taxonomic descriptions $(94,152,161,221,224)$, the following specific references to life-stage structure and function have been published.

CHROMOSOMES Both $H$. lineatum and $H$. bovis have six pairs of chromosomes with a diploid number of $12(33,112)$.

EGGS The structure and function of Hypoderma spp. eggs have been described (51) with emphasis on the specialized basal attachment organ.

LARVAE In-depth descriptions of Hypoderma spp. larvae have included the internal organs (56), the digestive tract (26), the Malpighian tubules (137), hemocytes $(138,203)$, the larval cuticle $(54,58,96,97)$, cuticular sensillae $(52,98)$, spiracles and respiration $(45,53,63,136,139,144,192)$, and the initiation of gonotrophic development in the late third-instar larvae $(25,143$, 193).

ADULTS Structure and function of the genitalia $(75,133,160)$, tarsal sensillae (55), mating behavior and mating site selection (46, 80, 213, 215, $216)$, flight $(49,146)$, and population dynamics $(9,36,37,39,108,129-131)$ of adult Hypoderma spp. have been described.

\section{Hosts}

Zumpt (224) hypothesized that the original host(s) of these two species of Hypoderma were extinct bovids once found in the warmer regions of Asia or Europe. Both species were probably introduced to North America in beef and 
dairy cattle (Bos taurus) imported from Europe (221) and subsequently infested bison (Bison bison), the only nearctic native animal in which these two Hypoderma species have been reported $(121,182)$. Additionally, they have been reported infesting closely related bovids such as yaks (38), and water buffalo and zebu cattle (140). A closely related species, Hypoderma (=Oedemagena) tarandi, the caribou warble fly, is holarctic in distribution (221). Other animal hosts parasitized by $H$. lineatum and $H$. bovis include horses $(82,151)$ and sheep and goats $(174)$, and there are numerous reports of human myiasis $(59,113,196)$. In these incidental hosts, Hypoderma spp. do not complete development and, therefore, have little effect on fly population levels. A report of completed larval development in an equine host (223) has not been repeated. Trials involving transplantation of first-instar larvae into recipient animals (18) failed to show alternate host suitability. Investigators infecting laboratory mice (71) and rabbits (32) with Hypoderma spp. larvae were successful only when they first immunosuppressed the host.

\section{Distribution}

$H$. bovis and $H$. lineatum occur naturally in cattle in at least 50 countries in North America, Europe, Africa, and Asia between 25 and $60^{\circ}$ latitude in the Northern Hemisphere (123). The southern limit is reached in the Punjab of India (202), Libya (19), northern Mexico (76), and Hawaii (1). Cattle grubs have been introduced into the Southern Hemisphere in imported cattle (11, $148,204,218)$, but it is unlikely that any ever established indigenous populations there (224).

In the U.S., $H$. lineatum ranges from northern Mexico to northern Canada, while $H$. bovis is found north of a line running west to east from northern Califomia through Kansas to the Carolinas (24). A small recurring population of $H$. bovis has been reported in central Florida (74).

The distribution of the two species in North America has remained essentially unchanged since the early part of the century (23). Larvae leaving the host during moderately cold weather are not destroyed by the direct effect of environment (164); they have a very wide tolerance range for cold (183) and diverse soil conditions (198). Susceptibility of puparia to high temperatures may be the factor limiting the southward distribution of $H$. bovis (165, 215). However, the indirect effect of climate on activity and viability of biotic agents such as arthropods, bacteria, and fungi may play a greater role than previously thought (188).

\section{CONTROL}

\section{Chemical Control}

Of the nearly 1400 citations reviewed for this article, more than $30 \%$ dealt with chemical control techniques and results. Drummond et al (64) and 
Berkenkamp \& Drummond (21) described the development of chemical control of cattle grubs in the U.S., and similar reviews have been presented for Canada (99) and Great Britain (13).

\section{Area-Wide Control}

The advent of systemic organophosphorus insecticides in the 1950s gave cattle producers the first opportunity to control cattle grubs on a large scale at a reasonable cost. Prior to this, cattle grubs were controlled by manual expression of second-and third-instar larvae from warbles or by the application of chemicals such as rotenone to the backs of animals to kill larvae in their warbles. The development of systemic insecticides provided an opportunity to kill migrating larvae prior to their arrival at the backline and thus avoided the damage done to hide and meat in that region. Because this strategy was prophylactic rather than reactive, proposals were made to eradicate Hypoderma spp. on a large scale using systemics alone (77). Coincidentally, however, researchers around the world were discovering that a combination of producer reluctance and biological rebound capacity were making such eradication schemes almost impossible to achieve $(176,210)$. Some maintained that vigilance and mobilization were all that were necessary (102a, 222a). The Province of Alberta in Canada and several European countries attempted concerted efforts to eradicate Hypoderma spp. Authors summarizing these attempts in Europe $(31,219)$ opined that much more remained to be done before this goal could be realized. Only Great Britain has faced the problem with complete and continuing government support in a national effort (205-207). The failure to elicit $100 \%$ cooperation from producers and dependence on a single strategy has led to the conclusion that cattle-grub control would be best approached with an integrated management program $(109,153)$.

The first attempt at integrated management of Hypoderma spp. resulted from the suggestion $(46,78)$ to adapt the sterile male-release technology that was developed for eradication of the screwworm (Cochliomyia hominivorax) from North America. The results of a preliminary trial in Alberta, Canada (214) were very encouraging, and consequently, the Joint U.S.-Canada Cattle Grub Project $(110,217)$ was initiated in 1982 . The chemical reduction phase proved to be very successful using readily available systemic insecticides combined with $100 \%$ producer cooperation (189). Even though there was a strong indication that releases of sterile males eliminated Hypoderma populations from the release zones, the objectives of the sterile fly component proved to be more difficult to achieve (111) due to the overwhelming logistical problems inherent with an insect for which there was no efficient technique for large-scale in vitro rearing (14). Nevertheless, an economic evaluation of the project demonstrated cost effectiveness, in spite of the difficulties encountered with production of sterile males (106). 


\section{Avermectins}

Perhaps the most promising control technology for use in eradication of Hypoderma spp. has been the development of the group of pharmaceuticals known as the avermectins. The first to be developed and tested for efficacy against cattle grubs and other parasites of cattle was Ivomec $®$ from Merck $(41,114,167)$. By the early 1980s this antiparasitic compound was being hailed as one of the most effective materials ever developed for systemic use against cattle grubs $(60,104)$. Despite concerns about possible environmental consequences from its use (212), Ivomec $\AA$ possesses unique characteristics not seen in organophosphorus systemics. The first of these is an ability to kill migrating larvae, but unlike systemics, it is also highly efficacious against second- and third-instar larvae in warbles (105). The latter activity permits use of this material as a late-season (194) or pour-on (2) treatment for grub-infested cattle that is not possible with traditional systemic insecticides, which are ineffective once the larvae are inside their warbles. Additionally, Ivomec $\AA$ produces $100 \%$ mortality of migrating Hypoderma larvae of both species at dramatically low dosage levels $(3,61)$. However, because it is used against a wide range of internal and external parasites, the lowest effective dilutions could lead to problems of resistance and reduced efficacy with other target species (114). Other avermectins in development that have already demonstrated similar efficacy against Hypoderma spp. are Moxidectin ${ }^{\circledR}$ from American Cyanamid (190) and Doramectin $\AA$ from Pfizer.

\section{Biological Control}

A review (188) of the few references pertaining to biological activity against Hypoderma spp. concluded that despite the scarcity of relevant literature, both distribution and population densities of cattle grubs might be more affected by parasites, predators, and pathogens than previously thought.

\section{Immune Response and Vaccines}

Hadwen \& Bruce (87), Koegel (107), and Peter (163) reported anaphylaxis in animals injected with macerated Hypoderma larvae. This anaphylactic reaction is similar to the results of treatment with systemic insecticides when migrating larvae are concentrated in their resting sites in the esophagus and spinal canal regions (102). Antigenic material from the hemolymph of the larvae or the material released by the disintegration of larvae killed by insecticide reacts with antibody in the tissues of the host and produces an allergic reaction with concomitant symptomology $(16,28)$.

Generally, fewer Hypoderma spp. larvae appear in the back of older cattle than in calves or yearlings (24), which implies the development of some type of immunity with age. The internal host-parasite regulating mechanism (129) probably has its origin in the host immune response system $(67,72)$. As early 
as the 1920s, researchers in France (181) and Germany (162) suggested using crude extracts of Hypoderma larvae to immunize animals. In Japan, efforts were made to characterize the toxic substance extracted from Hypoderma larvae, which Japanese researchers called hypodermatoxin (89-91, 154-156, 209). Simmons described the proteolytic activity associated with extracts of $H$. lineatum larvae (200) and the histopathological changes in the tissues of parasitized animals $(199,201)$.

Major advances have occurred in the past 15 years in the study of the biochemistry of Hypoderma digestive enzymes and of the bovine immune response to cattle-grub infestation. Four protease fractions have been isolated and described: hypodermin $C$ or collagenase $(8,27,30,115,117,118,120)$, hypodermin A (211), hypodermin B (119), and P2 (195). The amino.acid sequence of hypodermin $C$ has been reported (116), and hypodermin $A$ messenger RNA has been prepared from first-instar larvae of $H$. lineatum (208). A potential parasite-induced immunosuppressive mechanism by the degradation of host complement protein $\mathrm{C} 3$ by the hypodermins $\mathrm{A}$ and $\mathrm{B}$ was reported $(5,29)$. Descriptions also have been reported of the antigenicity and immunogenicity of $H$. lineatum proteins in rabbit (32) and bovine hosts (168, $173)$, and of the shared epitopes between the soluble proteins of $H$. lineatum and $H$. bovis (172).

Initial investigations using extracts of Hypoderma spp. larvae as candidate vaccines $(7,103,125,169,180,197)$ have led to concerted attempts toward the development of a defined vaccine against cattle-grub infections. Instead of extracts from collected larvae, these defined vaccines have focused upon the principal protein antigens of first-instar larval $H$. lineatum, hypodermins A, B, and C. Hypodermin A has been evaluated in pure form $(47,68,170$, $171)$, and the other hypodermins in various combinations $(6,171)$.

The advantages of a vaccine over chemical control are great; less damage to the environment, complete and lifetime conversion of susceptible animals to resistant status, and use in animals such as dairy cattle for which systemic insecticide application is prohibited during lactation, to name a few. Experimental vaccine efficacy has been manifested as an increase in total in vivo larval parasitic mortality. Experimental vaccines have not, to date, protected the subcutaneous tissues of the back and prevented hide damage in individual animals by significantly increasing mortality in migrating larvae. However, because of the increase in mortality to those larvae arriving at the back, current experimental vaccines are designed to increase overall larval mortality and therefore reduce the levels of Hypoderma spp. populations. However, these experimental vaccines have not been field-tested against naturally occurring populations of Hypoderma. If population reduction can be achieved, the lower efficacy of vaccines presumably will require 
a longer period of time to reach acceptable levels of control than has been observed with conventional chemical control technology. Thus, experimental vaccines already developed may have limited value for use in intensive control programs designed to reduce the cattle-grub population drastically over a short period of time (47). Vaccines may, on the other hand, be useful in less intensive control programs and as a complement instead of a substitute for chemical control in integrated management programs. If acquired immunity can be maintained for the life of the animal and herd immunity maintained by vaccination, dramatic and rapid cattle-grub population growth as a result of withdrawal of or reduction in chemical control pressure may be greatly retarded or maintained at subeconomic levels. Because vaccines do not elicit the complete efficacy that systemic insecticides do, we may need to redefine long held concepts relating to economic thresholds and control. Finally, the increased understanding of the cattle immune response system as it interacts with Hypoderma spp. has far-reaching implications for other host-parasite relationships.

During the past several years, the prevalence of both Hypoderma species has declined dramatically (187) in North America. This is especially true of $H$. bovis, which has all but disappeared west of the Mississippi River (D. D. Colwell \& J. E. Lloyd, personal communication). The cause(s) for this decline is (are) unknown. Possibly the widespread use of systemic insecticides, especially the avermectins, on and in range and feedlot cattle in this region, or changes in the environment, have driven the population of $H$. bovis below an undefined critical level.

Improved, safer insecticides combined with advances in the understanding of Hypoderma spp. biology and ecology and of the bovine immune system interacting with these parasites may have finally put control or even eradication of the two Hypoderma species within reach. To achieve sustained control or eradication, the interest of producers and researchers in cattle-grub biology and control must remain high for at least the next decade.

\section{ACKNOWLEDGMENTS}

The author dedicates this review to Jerry Weintraub for his inspiration and lifetime of contributions to this subject. I also thank E. Paul Catts, Jr., Robert D. Hall, Jerome A. Hogsette, and John H. Pruett for manuscript review and helpful suggestions; L. June Ford for manuscript preparation; and Sidney E. Kunz and the USDA-ARS Knipling-Bushland U.S. Livestock Insects Research Laboratory for support. 


\section{Literature Cited}

1. Alicata, J. E. 1964. Parasitic infections of man and animals in Hawaii. Hawaii Agric. Exp. Stn. Tech. Bull. 61. 138 pp.

2. Alva-Valdes, R., Wallace, D. H., Holste, J. E., Egerton, J. R., Cox, J. L., et al. 1986. Efficacy of ivermectin in a topical formulation against induced gastrointestinal and pulmonary nematode infections, and naturally acquired grubs and lice in cattle. Am. J. Vet. Res. 47:2389-92

3. Argente, G., Hillion, E. 1984. Use of small doses of ivermectin for preventing bovine hypodermatosis. Point Vet. 16: 614-18 (In French)

4. Ashizawa, H., Taguchi, Y., Nagao, K., Nosaka, D., Tateyama, S. 1976. Pathological findings of warble swellings caused by Hypoderma larvae in the bovine skin. Bull. Fac. Agric. Univ. Miyazaki 23:87-95 (In Japanese with English summary)

5. Baron, R. W. 1990. Cleavage of purified bovine complement component C3 in larval Hypoderma lineatum (Diptera: Oestridae) hypodermins. J. Med. Entomol. 27:899-904

6. Baron, R. W., Colwell, D. D. 1991. Enhanced resistance to cattle grub infestation (Hypoderma lineatum de Vill.) in calves immunized with purified hypodermin A, B, and C plus monophosphoryl lipid A (MPL). Vet. Parasitol. 38:185-97

7. Baron, R. W., Weintraub, J. 1986. Immunization of cattle against hypodermatosis [Hypoderma lineatum (Devill.) and $H$. bovis (L.)] using $H$. lineatum antigens. Vet. Parasitol. 21: 43-50

8. Baron, R. W., Weintraub, J. 1987. Immunological responses to parasitic arthropods. Parasitol. Today 3:77-82

9. Bart, A. G., Minar, J. 1984. Basic regulatory parameters of the host-parasite system for warble flies of farm animals using Hypoderma bovis as an example. Folia Parasitol. (Prague) 31: 277-87

10. Batte, E. G. 1972. Differential diagnosis of parasitic dermatitis of cattle. J. Am. Vet. Med. Assoc. 161:1265-68

11. Bedford, G. A. H. 1926. Check-list of the Muscidae and Oestridae which cause myiasis in man and animals in South Africa. Union S. Afr. Dept. Agric. Res. Div. Vet. Educ. Res. 11/12: 483-91

12. Beesley, W. N. 1961. Observations on the development of Hypoderma lineatum de Villers (Diptera, Oestridae) in the bovine host. Ann. Trop. Med. Parasitol. 55:18-24

13. Beesley, W. N. 1966. The use in Britain of systemic insecticides for the control of Hypoderma (Diptera: Oestridae). Vet. Med. Rev. 1:37-48

14. Beesley, W. N. 1967. Observations on the biology of the ox warble-fly (Hypoderma: Diptera, Oestridae). I. In vitro culture of the first-instar larva. Ann. Trop. Med. Parasitol. 61:175-81

15. Beesley, W. N. 1968. Observations on the biology of the ox warble-fly (Hypoderma: Diptera, Oestridae). II. Bacteriostatic properties of larval exracts. Ann. Trop. Med. Parasitol. 62: 8-12

16. Beesley, W. N. 1971. Observations on the biology of the ox warble, (Hypoderma: Diptera, Oestridae). V. Anaphylactoid shock in laboratory animals and calves following exposure to extracts of larvae of Hypoderma. Ann. Trop. Med. Parasitol. 65:567-72

17. Beesley, W. N. 1974. Economics and progress of warble fly eradication in Britain. Vet. Med. Rev. 4:334-47

18. Beesley, W. N., Davies, S. F. M. 1959. The implantation of first-instar larvae of Hypoderma into experimental animals. Vet. Rec. 71:21-23

19. Beesley, W. N., Gabaj, M. M. 1991. New records for Rhipicephalus bursa, Boophilus microplus, $B$. decoloratus and Hypoderma lineatum from Libya. Med. Vet. Entomol. 5:259-60

20. Beesley, W. N., Murray, V. I. E. 1968. The mouthparts of the ox warble fly, Hypoderma (Diptera: Hypodermatidae). Trans. R. Soc. Trop. Med. Hyg. 62:471-72

21. Berkenkamp, S. D., Drummond, R. O. 1990. Hypodermosis--part II. Compendium 12:881-88

22. Bevan, W. J., Edwards, E. E. 1951. Studies on the ox warble flies, Hypoderma lineatum and Hypoderma bovis. Bull. Entomol. Res. 41:639-62

23. Bishopp, F. C. 1915. The distribution and abundance of the ox warbles, Hypoderma lineata and $H$. bovis in the United States. Ann. Entomol. Soc. Am. 8:359-64

24. Bishopp, F. C., Laake, E. W., Brundrett, H. M., Wells, R. W. 1926. The cattle grubs or ox warbles, their biologies and suggestions for control. U.S. Dept. Agric. Bull. 1369. 119 pp. 
25. Boulard, C. 1968. Differenciation et developpement des gonades males et femelles chez les larves d'Hypoderma bovis et d'Hypoderma lineatum (Dipt., groupe biologique des Oestriformes). Ann. Soc. Entomol. Fr. 4:349-64

26. Boulard, C. 1969. Anatomie et histologie du tube digestif de la larve d'Hypoderma bovis (Diptere: Oestriforme). Ann. Soc. Entomol. Fr. 5:371-87

27. Boulard, C. 1970. A preliminary study of a crude collagenase extract of the first-instar larva of Hypoderma lineatum (de Villers). C. R. Acad. Sci. Ser. D 270:1349-51 (In French)

28. Boulard, C. 1979. Circulating antibodies and blood histamine in cattle after treatment against hypodermosis. Vet. Parasitol. 5:379-87

29. Boulard, C. 1989. Degradation of bovine $\mathrm{C} 3$ by serine proteases from parasites Hypoderma lineatum (Diptera, Oestridae). Vet. Immunol. Immunopathol. 20:387-98

30. Boulard, C., Garrone, R. 1978. Characterization of a collagenolytic enzyme from larvae of Hypoderma lineatum (Insecta: Diptera, Oestriform). Comp. Biochem. Physiol. B 59:251-55

31. Boulard, C., Thornberry, H., eds. 1984. Warble Fly Control in Europe. Rotterdam/Boston: Balkema. 156 pp.

32. Boulard, C., Weintraub, J. 1973. Immunological responses of rabbits artificially infested with the cattle grubs Hypoderma bovis (L.) and $H$. lineatum (De Vill.) (Diptera: Oestridae). Int. J. Parasitol. 3:379-86

33. Boyes, J. W. 1964. Somatic chromosomes of higher Diptera. VIII. Karyotypes of species of Oestridae, Hypodermatidae, and Cuterebridae. Can. J. Zool. 42:599-604

34. Brauer, F. M. 1863. Monographie der Oestriden. Vienna: Carl Veberrentez. $291 \mathrm{pp}$.

35. Breev, K. A. 1967. New data on the migration of first-instar larvae of $\mathrm{Hypo}$ derma bovis De Geer in the host organism. Parazitol. Sb. 23:191-221

36. Breev, K. A. 1968. On the distribution of warble-fly larvae (Hypoderma bovis [L.] and $H$. lineatum [Vill.]) in herds of cattle. I. Negative binomial distribution as a model of the distribution of warble-fly larvae. Parazitologiya 2: 322-33 (In Russian with English summary)

37. Breev, K. A. 1969. On the distribution of warble-fly larvae (Hypoderma bovis [L.] and $H$. lineatum [Vill.]) in herds of cattle. II. Exponent $k$ of negative binomial distribution as a measure of the dispersion of the infestation of animals with warble-flies. Parazitologiya 2:381-94 (In Russian with English summary)

38. Breev, K. A., Baratov, S. B. 1970. On the warble-fly of yaks in the Pamirs. Parazitologiya 4:241-49 (In Russian with English summary)

39. Breev, K. A., Minar, J. 1976. On the regularities of distribution of $\mathrm{Hypo}$ derma bovis De Geer larvae parasitizing cattle herds in different parts of the range of this warble fly. Folia Parasitol. (Prague) 23:343-56

40. Bruce, W. G. 1938. Soil moisture and its relation to the mortality of Hypoderma pupae. J. Econ. Entomol. 31: 639-42

41. Campbell, W. C., Fisher, M. H., Stapley, E. O., Albers-Schonberg, G., Jacob, T. A. 1983. Ivermectin: a potent new antiparasitic agent. Science 221: 823-28

42. Carpenter, G. H., Hewitt, T. R. 1914. The reproductive organs and the newly hatched larva of the warble-fly (Hypoderma). R. Dublin Soc. Sci. Proc. 14:268-89

43. Carpenter, G. H., Hewitt, T. R. 1914. Some new observations on the lifehistory of warble flies: the entrance of the maggot into the host's body. Ir. Nat. 23:214-21

44. Carpenter, G. H., Hewitt, T. R., Reddin, T. K. 1914. The warble flies: fourth report on experiments and observations as to life-history and treatment. I. New facts in the life-history. J. Dept. Agric. Tech. Inst. (Ireland) 15:105-32

45. Carpenter, G. H., Pollard, F. J. S. 1918. The presence of lateral spiracles in the larva of Hypoderma. Proc. $R$. Ir. Acad. (Dublin) 34:73-84

46. Catts, E. P., Garcia, R., Poorbaugh, J. H. 1965. Aggregation sites of males of the common cattle grub, Hypoderma lineatum (DeVillers) (Diptera: Oestridae). J. Med. Entomol. 1:357-58

47. Chabaudie, N., Villejoubert, C., Boulard, C. 1991. The response of cattle vaccinated with hypodermin $\mathrm{A}$ to a natural infestation of Hypoderma bovis and Hypoderma lineatum. Int. J. Parasitol. 21:859-62

48. Chamberlain, W. F., Barrett, C. C., Graham, O. H. 1969. Integumental absorption versus oral ingestion of phosphate and other materials by common cattle grubs held in vitro. Ann. Entomol. Soc. Am. 62:843-46

49. Chamberlain, W. F., Barrett, C. C., Miller, J. A. 1986. Effect of gamma 
irradiation on flight time of Hypoderma lineatum (Diptera: Oestridae) males. Ann. Entomol. Soc. Am. 79:289-92

50. Clark, B. 1827. Of the insect called oistros by the ancients, and of the true species intended by them under this appellation: in reply to the observations of W. S. MacLeay, Esq., and the French naturalists. Trans. Linn. Soc. London 15:402-11

51. Cogley, T. P., Anderson, J. R., Weintraub, J. 1981. Ultrastructure and function of the attachment organ of warble fly eggs (Diptera: Oestridae: Hypodernatinae). Int. J. Insect Morphol. Embryol. 10:7-18

52. Colwell, D. D. 1986. Cuticular sensilla on newly hatched larvae of Cuterebra fontinella Clark (Diptera: Cuterebridae) and Hypoderma spp. (Diptera: Oestridae). Int. J. Insect Morphol. Embryol. 15:385-92

53. Colwell, D. D. 1989. Scanning electron microscopy of the posterior spiracles of cattle grubs Hypoderma bovis and Hypoderma lineatum. Med. Vet. Entomol. 3:391-98

54. Colwell, D. D. 1991. Ultrastructure of the integument of first-instar Hypoderma lineatum and $H$. bovis (Diptera: Oestridae). J. Med. Entomol. 28:86-94

55. Colwell, D. D., Berry, N. M. 1992. Tarsal sensilla of warble flies Hypoderma bovis and $H$. lineatum (Diptera: Oestridae). Ann. Entomol. Soc. Am. In press

56. Cooke, M. L. 1968. The internal anatomy of the larval instars of Hypoderma lineatum (De Villiers). $\mathrm{PhD}$ thesis. Purdue Univ. $103 \mathrm{pp}$.

57. Cox, D. D., Mozier, J. O., Mullee, M. T. 1970. Posterior paralysis in a calf caused by cattle grubs (Hypoderma bovis) after treatment with a systemic insecticide for grub control. J. Am. Vet. Med. Assoc. 157:1088-92

58. Dennell, R. 1978. The laminae and pore canals of some arthropod cuticles. Zool. J. Linn. Soc. 64:241-50

59. Doby, J. M., Deunff, J., Couatarmanach, A., Guiguen, C. 1985. Human hypodermosis in France in 1984. Bull. Soc. Pathol. Exot. 78:205-15 (In French with English summary)

60. Dorchies, P., Franc, M., de Lahitte, J. D. 1982. Antiparasitic treatment of cattle by ivomectine. Rev. Med. Vet. 133:709-13 (In French with English summary)

61. Drummond, R. O. 1985. Effectiveness of ivcrmectin for control of arthropod pests of livestock. Southwest. Entomol. 7:34-42 (Suppl.)
62. Drummond, R. O. 1987. Economic aspects of ectoparasites of cattle in North America. In The Economic Impact of Parasitism in Cattle. Proc. MSD AGVET Symposium, 23rd World Vet. Congr., Montreal, 1987, ed. W. H. D. Leaning, J. Guerrero, pp. 9-24. Rahaway, NJ: MSD AGVET

63. Drummond, R. O., Chamberlain, W. F. 1961. Studies on respiration of cattle grubs. Ann. Entomol. Soc. Am. 54:524-26

64. Drummond, R. O., George, J. E., Kunz, S. E. 1987. Control of cattle grubs in cattle. In Control of Arthropod Pests of Livestock: A Review of Technology, pp. 77-91. Boca Raton: CRC Press. 245 pp.

65. Drummond, R. O., Lambert; G., Smalley, H. E. Jr., Terrill, C. E. 1981. Estimated losses of livestock to pests. In CRC Handbook of Pest Management in Agriculture, ed. D. Pimentel, 1:111-27. Boca Raton: CRC Press. 597 pp.

66. Everett, A. L., Miller, R. W., Gladney, W. J., Hannigan, M. V. 1977. Effects of some important ectoparasites on the grain quality of cattlehide leather. J. Am. Leather Chem. Assoc. 72:6-24

67. Evstaf'ev, M. N. 1980. The role of immunity during Hypoderma infestation of cattle. Parazitologiya 14:197205 (In Russian with English summary)

68. Fisher, W. F., Pruett, J. H., Howard, V. M., Scholl, P. J. 1991. Antigenspecific lymphocyte proliferative responses in vaccinated and Hypoderma lineatum-infested calves. Vet. Parasitol. 40:135-45

69. Gansser, A. W. E. 1956. Warble Flies and Other Oestridae: Biology and Control. Surrey, UK: Hide and Allied Trades Improvement Soc. 63 pp.

70. Gebauer, O., Eichler, W., Breev, K. A., Nogge, G. 1974. The two species of warble-flies of cattle, Hypoderma bovis and Hypoderma lineatum. Merkbl. Angew. Parasitenkd. Schaedlingsbekaempf. 20:1-30 (In German)

71. Gingrich, R. E. 1970. Survival of first-instar larvae of Hypoderma lineatum (Diptera: Oestridae) implanted in heterologous murine hosts. J. Med. Entomol. 7:256-60

72. Gingrich, R. E. 1980. Differentiation of resistance in cattle to larval Hypoderma lineatum. Vet. Parasitol. 7:24354

73. Gingrich, R. E. 1982. Acquired resistance to Hypoderma lineatum: comparative immune response of resistant 
and susceptible cattle. Vet. Parasitol. 9:233-42

74. Glick, J. I. 1976. Infestation of native Florida cattle with the northern cattle grub, Hypoderma bovis (Diptera: Oestridae). Fla. Entomol. 59:190

75. Gooding, R. H., Weintraub, J. 1960. The genitalia of Hypoderma bovis (L.) and $H$. lineatum (de Vill.) (Diptera: Oestridae). Can. J. Zool. 38:56574

76. Graham, O. H. 1965. Occurrence of Hypoderma lineatum (De Villers) in northem Mexico. J. Med. Entomol. 2:308

77. Graham, O. H., Drummond, R. O. 1967. The potential of animal systemic insecticides for eradicating cattle grubs, Hypoderma spp. J. Econ. Entomol. 60:1050-53

78. Graham, O. H., Hourrigan, J. L. 1977. Eradication programs for the arthropod parasites of livestock. J. Med. Entomol. 13:629-58

79. Gregson, J. D. 1958. Recent cattle grub life-history studies at Kamloops, British Columbia, and Lethbridge, Alberta. Proc. Int. Congr. Entomol., 1956, 10th 3:725-34. Ottawa: Mortimer

80. Grunin, K. Y. 1959. Aggregations of botfly males on the highest points in locality and their cause. Zool. Zh. 38:1683-88 (In Russian with English summary)

81. Grunin, K. Y. 1962. Warble flies (Hypodermatidae). Fauna URSS, Insecta: Diptera 19 no. 4, 237 pp. Moscow, Leningrad (In Russian)

82. Hadlow, W. J., Ward, J. K., Krinsky, W. L. 1977. Intracranial myiasis by Hypoderma bovis (Linnaeus) in a horse. Cornell Vet. 67:272-81

83. Hadwen, S. 1912. The economic aspect of warble flies. Can. Dept. Agric. Health/Anim. Branch Bull. 16. 20 pp.

84. Hadwen, S. 1916. The seasonal prevalence of Hypoderma bovis in 1915, together with observations on the terrifying effect $H$. bovis has upon cattle, and lesions produced by the larva. Entomol. Soc. Ont. Annu. Rep. 36: 108-19

85. Hadwen, S. 1919. Warble flies: Hypoderma lineatum, Villers and Hypoderma bovis, De Geer. Can. Dept. Agric. Health/Anim. Sci. Ser. 27. 24

86. Hadwen, S., Bruce, E. A. 1916. Observations on the migration of warble larvae through the tissues. Can. Dept. Agric. Health. Anim. Branch Bull. 22. 14 pp.
87. Hadwen, S., Bruce, E. A. 1917. Anaphylaxis in cattle and sheep, produced by the larvae of Hypoderma bovis, $H$. lineatum and Oestrus ovis. J. Am. Vet. Med. Assoc. 11:15-44

88. Hadwen, S., Fulton, J. S. 1924. On the migration of Hypoderma lineatum from the skin to the gullet. Parasitology 16:98-106

89. Haga, T. 1944. Biochemical studies on the "hypodermatotoxin." I. Physical and chemical properties of the venom. Jpn. J. Vet. Sci. 6:126

90. Haga, T. 1944. Biochemical studies on the "hypodermatotoxin." II. Enzymes in the venom. Jpn. J. Vet. Sci. 6:135

91. Haga, T. 1944. Biochemical studies on the "hypodematotoxin." III. Gelatinolytic and other biochemical activities of the venom. Jpn. J. Vet. Sci. 6:206

92. Haines, B. M. 1978. Factors influencing the quality of leather. Meat Hyg. 17:24-30

93. Imms, A. D. 1906. On the life-histories of the ox warble flies Hypoderma bovis (De Geer), and $H$. lineata (Villers). J. Econ. Biol. 1:74-91

94. James, M. T. 1947. The flies that cause myiasis in man. U.S. Dept. Agr. Misc. Publ. 631. 175 pp.

95. Jettmar, H. M. 1953. Uber bakteriostatische stoffe im darm der hypodermalarve. Z. Hyg. Infectionskr. 137: 61-66

96. Kennaugh, J. H. 1965. Pore canals in the cuticle of Hypoderma bovis (Diptera). Nature 205:207

97. Kennaugh, J. H. 1972. Some observations on the cuticle of the larvae of Hypoderma bovis and Hypoderma diana (Oestridae). Parasitology 65: 121-30

98. Kennaugh, J. H. 1973. Sense organs in the cuticle of larval Hypoderma bovis (L.) and $H$. diana Brauer (Dipt., Oestridae). Bull. Entomol. Res. 62: 419-21

99. Khan, M. A. 1969. Systemic pesticides for use on animals. Annu. Rev. Entomol. 14:369-86

100. Khan, M. A. 1969. Significance of "spinal-stage" Hypoderma larvae in systemic insecticide toxicity. Res. Vet. Sci. 10:355-60

101. Khan, M. A. 1971. Some factors involved in systemic insecticide toxicosis: esophageal lesions in heifers reated with coumaphos, crufomate and trichlorfon. Can. J. Anim. Sci. 51:411-17

102. Khan, M. A. 1973. Toxicity of systemic insecticides: toxicological con- 
siderations in using organophosphorus insecticides. Vet. Rec. 92:411-19

102a. Khan, M. A. 1977. The feasibility of exterminating warble flies (Hypoderma spp.) on a regional basis. Vet. Parasitol. 3:217-23

103. Khan, M. A., Connell, R., le Q. Darcel, C. 1960. Immunization and parenteral chemotherapy for the control of cattle grubs Hypoderma lineatum (De Vill.) and $H$. bovis (L.) in cattle. Can. J. Comp. Med. 24:177-80

104. Khan, M. A., Hironaka, R., Schaalje, G. B. 1983. Effectiveness of Ivomec for systemic control of warble grubs. In Research Highlights-1982, pp. 4245. Lethbridge, Alta.: Agric. Can. Res. Stn.

105. Khan, M. A., Scholl, P. J., Weintraub, J. 1985. Ivomec for control of hypodermal larvae. In Pesticide Research Report-1984, pp. 193. Ottawa, Canada: Expert Comm. Pest. Use Agric.

106. Klein, K. K., Fleming, C. S., Colwell, D. D., Scholl, P. J. 1990. Economic analysis of an integrated approach to cattle grub (Hypoderma spp.) control. Can. J. Agric. Econ. 38:159-73

107. Koegel, A. 1924. Praecipitations und anaphylaxieversuche mit parasitenextrakten-(Larven von Hypoderma bovis, Gasterophilus equi und Gasterophilus haemorrhoidalis). Muench. Tierarztl. Wochenschr. 75:945-54

108. Kolacz, J. 1975. Dynamics of bovine gadfly invasion. Med. Weter. 31:65961 (In Polish with English summary)

109. Kunz, S. E. 1987. Integrated pest management of dipteran pests in the New World. Int. J. Parasitol. 17:659 64

110. Kunz, S. E., Drummond, R. O., Weintraub, J. 1984. A pilot test to study the use of the sterile insect technique for eradication of cattle grubs. Prev. Vet. Med. 2:523-27

111. Kunz, S. E., Scholl, P. J., Colwell, D. D., Weintraub, J. 1990. Use of the sterile insect technique for control of cattle grubs (Hypoderma lineatum and $H$. bovis) (Diptera: Oestridae). J. Med. Entomol. 27:523-29

112. LaChance, L. E. 1964. Chromosome studies in three species of Diptera (Muscidae and Hypodermatidae). Ann. Entomol. Soc. Am. 57:69-73

113. LaPierre, J. 1977. II. Myiasis diseases. Diseases caused by Hypoderma. Concours Med. 99:7375-79 (In French)

114. Leaning, W. H. D. 1984. Ivermectin as an antiparasitic agent in cattle. Mod. Vet. Pract. 65:669-72

115. Lecroisey, A., Boulard, C., Keil, B.
1979. Chemical and enzymatic characterization of the collagenase from the insect Hypoderma lineatum. Eur. J. Biochem. 101:385-93

116. Lecroisey, A., Giles, A., De Wolf, A., Keil, B. 1987. Complete amino acid sequence of the collagenase from the insect Hypoderma lineatum. J. Biol. Chem. 262:7546-51

117. Lecroisey, A., Keil, B. 1983. Structural study on the active site of the collagenase from Hypoderma lineatum. Biochem. Biophys. Res. Commun. 112: 907-10

118. Lecroisey, A., Keil, B. 1985. Specificity of the collagenase from the insect Hypoderma lineatum. Eur. J. Biochem. 152:123-30

119. Lecroisey, A., Tong, N. T., Keil, B. 1983. Hypodermin B, a trypsin-related enzyme from the insect Hypoderma lineatum: comparison with hypodermin A and Hypoderma collagenase, two serine proteinases from the same source. Eur. J. Biochem. 134:261-67

120. Lienert, E., Thorsell, W. 1956. In vitro inhibition experiments on the system: collagenase of the spinal larvae of Hypoderma bovis collagen. Wiener Tieraerztl. Monatsschr. 43:746-51 (In German)

121. Locker, B. 1953. Parasites of bison in northwestern U.S.A. J. Parasitol. 39: $58-59$

122. Ludwig, P. D., Bucek, O. C. 1966. Cattle grub control of economic importance. Pract. Vet. 38:32-34

123. Luhrs, E. 1958. Die verbreitung der dasselfliegen (Hypoderma bovis und lineata) auf der erde. Dtsch. Tieraerztl. Wochenschr. 65:88-93

124. MacDougall, R. S. 1934. Ox warble flies. Trans. Highl. Agric. Soc. Scotl. 46:1-90

125. Magat, A., Boulard, C. 1970. Essais de vaccination contre l'hypodermose bovine avec un vaccin contenant une collagenase brute extraite des larves de ler stade d'Hypoderma lineatum. C. R. Acad. Sci. Paris 270:728-30

126. Markus, G. 1970. Investigations on the healing process of warble lesions in the skin of cattle. Vet. Bull. 40:1187 (Abstr.) (In German)

127. Matthes, H. F., Hiepe, T. 1987. Raw hide and leather damage caused by arthropods, helminths, and protozoa. Monatsh. Veterinaermed. 42:212-16 (In German with English summary)

128. McLintock, J. 1964. Puparium formation in Diptera. Nature (London) 201: 1245

129. Minar, J. 1984. Population ecology of 
Hypoderma bovis (de Geer) and its importance for hypodermosis control. See Ref. 31, pp. 141-48

130. Minar, J. A. 1986. Internal regulatory systems---common consistent patterns in the parasite-host relationships with specific parasites. Folia Parasitol. (Prague) 33:71-75

131. Minar, J., Breev, K. A. 1983. Studies on the low and fundamental populations of the warblc fly Hypoderma bovis (De Geer) (Diptera, Hypodermatidae). Folia Parasitol. (Prague) 30:57-71

132. Mote, D. C. 1928. The ox warble flies. Ohio Agric. Exp. Stn. Bull. 428. $45 \mathrm{pp}$.

133. Mote, D. C. 1929. The reproductive system of the warble fly Hypoderma bovis DeGeer. Ann. Entomol. Soc. Am. 22:70-80

134. Mozier, J. O. 1969. Advances in cattle ectoparasite control with a discussion of some problems related to treatment with systemic insecticides. J. Am. Vet. Med. Assoc. 154:1206-13

135. Mullee, M. T., Nelson, D. L., Cox, D. D. 1968. Adverse reactions to Hypoderma bovis in two of 1,127 calves reated for control of grubs. Vet. Med./Sm. Anim. Clin. 63:876-77

136. Murray, V. I. E. 1971. The tracheal system of the larvae of Hypoderma (Diptera: Oestridae) lineatum and $H$. bovis. Can. Entomol. 103:1397-1404

137. Murray, V. I. E. 1971. The malpighian tubules of the larvae of Hypoderma (Diptera: Oestridae) lineatum and $H$. bovis. Can. Entomol. 103:1727-32

138. Murray, V. I. E. 1972. The haemocytes of Hypoderma (Diptera: Oestridae). Proc. Entomol. Soc. Ont. 102:46-63

139. Murray, V. I. E. 1974. Development of the posterior spiracles in Hypoderma (Diptera: Hypodermatidae) lineatum and H. bovis. Can. Entomol. 106:11320

140. Mustafaev, A. S. 1970. The infestation of zebu and water buffalo by warbleflies in the Azerbaijan SSR. Parazitologiya 4:433-36 (In Russian with English summary)

141. Natvig, L. R. 1937. On ox warbleflies and their occurrence in Norway. Nor. Vet.-Tidsskr. 49:171-204, 217$51,271-98,335-58,378-406,436-$ 70 (In Norwegian with English summary, pp. 449-60)

142. Nelson, W. A., Weintraub, J. 1972. Hypoderma lineatum (De Vill.) (Diptera: Oestridae): Invasion of the bovine skin by newly hatched larvae. J. Parasitol. 58:614-24

143. Nogge, G. 1967. Ovarienentwicklung und oenocyten in der larve der grossen dasselfliege: Hypoderma bovis (De Geer)(Diptera, Oestridae). $\mathrm{PhD}$ thesis. Univ. Bonn, Bonn, Germany. 27 pp.

144. Nogge, G. 1970. The growth and oxygen consumption of larvae of Hypoderma bovis (De Geer) (Diptera, Hypodermatidae). Oecologia 4:381-90 (In German with English summary)

145. Nogge, G. 1973. The temperature in warbles of Hypoderma bovis and Crivellia silenus. Angew. Parasitol. 14:152-57 (In German with English summary)

146. Nogge, G., Staack, W. 1969. The flight behavior of the warble fly (Hypoderma latreille) (Diptera, Hypodermatidae) and the agitation of cattle. Behavior 35:200-11 (In German with English summary)

147. Nogge, G., Werner, H. 1970. Investigations on the contents of bacteria in larvae and boils of Hypoderma bovis (De Geer), Diptera, Hypodermatidae. Zentralbl. Bakteriol. Parasitenkd. Infektionskr. Hyg. Abt. 2 125:326-30 (In German with English summary)

148. Oberg, C., Diaz, L., Valenzuela, G. 1974. Parasites identified in cattle, sheep, pigs and equines in the Laboratory of Parasitic Diseases of the School of Veterinary Medicine, University Austral of Chile, 1963-73. Bol. Chil. Parasitol. 29:99-102 (In Spanish)

149. O'Flaherty, F., McLaughlin, G. D. 1930. Some histological studies of the effects of grubs upon animal skin. Am. Leather Chem. Assoc. J. 25:266-70

150. O'Flaherty, F., Roddy, W. T., Jackson, L. B. 1949. Hide and Skin Defects. New York: Hide Bureau, Tanners' Council of America. 39 pp.

151. Olander, H. J. 1967. The migration of Hypoderma lineatum in the brain of a horse. Pathol. Vet. 4:477-83

152. Oldroyd, H. 1977. The suborders of Diptera. Proc. Entomol. Soc. Wash. 79:3-10

153. Olkowski, W. 1986. Update: new opportunities for comprehensive cattle grub management. IPM Pract. 8(6/7): 1-9

154. Ono, S. 1931. Studies on "hypodermatotoxin," toxin obtained from the larvae of Hypoderma sp. at the oesophageal stage. 1. Its action on the blood coagulation. J. Jpn. Soc. Vet. Sci. 10:230-31

155. Ono, S. 1932. Studies on "hypodermatotoxin," toxin obtained from the larvae of Hypoderma sp. at the oesophageal stage. 2. Biologic significance of hypodermatotoxin from point 
of view of its hemorrhagenic and dermolytic actions. J. Jpn. Soc. Vet. Sci. 11:53-55

156. Ono, S. 1933. Morphologic studies on larvac of Hypoderma lineatum at the esophageal and hypodermic stages, with special reference to the organ containing "hypodermatotoxin." J.Jpn. Soc. Vet. Sci. 11:220-23

157. Ormerod, E. A. 1894. Observations on Warble Fly or Ox Bot Fly, Hypoderma bovis, DeGeer. London: Simkin, Marshall, Hamilton, Kent. 62 pp.

158. Osbom, H. 1896. The bot flies of cattle: warble flies. U.S. Dept. Agric. Div. Entomol. Bull. 5:87-101

159. Papavero, N. 1977. The World Oestridae (Diptera), Mammals and Continental Drift. The Hague: Junk. 240 pp.

160. Patton, W. S. 1935. Studies on the higher Diptera of medical and veterinary importance: a revision of the species of the genus Glossina Wiedemann based on a comparative study of the male and female terminalia. Ann. Trop. Med. Parasitol. 29:303-15

161. Patton, W. S. 1936. Studies on the higher Diptera of medical and veterinary importance: the warble flies of the genus Hypoderma. Ann. Trop. Med. Parasitol. 30:453-68

162. Peter, B. 1929. Immunization of cattle against the larvae of the ox warble fly. A theoretical consideration. Berl. Tieraerztl. Wochenschr. 1929:209 (In German)

163. Peter, B. 1934. The experimental production of anaphylactic conditions with extracts of Hypoderma larvae. Berl. Tieraerztl. Wochenschr. 50:241-43 (In German)

164. Pfadt, R. E. 1947. Effects of temperature and humidity on larval and pupal stages of the common cattle grub. $J$. Econ. Entomol. 40:293-300

165. Pfadt, R. E., Lloyd, J. E., Sharafi, G. 1975. Pupal development of cattle grubs at constant and altemating temperatures. J. Econ. Entomol. 68:325-28

166. Prchal, C. J. 1964. The importance of the common cattle grub (Hypoderma lineatum) to meat inspection. J. Am. Med. Vet. Assoc. 146:39-40

167. Preston, J. M. 1984. The avermectins: new molecules for use in warble fly control. See Ref. 31, pp. 17-20

168. Pruett, J. H., Barrett, C. C. 1984. Induction of intradermal skin reactions in the bovine by fractionated proteins of Hypoderma lineatum. Vet. Parasitol. 16:137-46
169. Pruett, J. H., Barrett, C. C. 1985. Kinetic development of humoral antiHypoderma lineatum antibody activity in the serum of vaccinated and infested cattle. Southwest. Entomol. 10:39-48

170. Pruett, J. H., Barrett, C. C., Fisher, W. F. 1987. Kinetic development of serum antibody to purified Hypoderma lineatum proteins in vaccinated and nonvaccinated cattle. Southwest. Entomol. 12:79-88

171. Pruett, J. H., Fisher, W. F., Temeyer, K. B. 1989. Evaluation of purified proteins of Hypoderma lineatum as candidate immunogens for a vaccine against bovine hypodermiasis. Southwest. Entomol. 14:363-73

172. Pruett, J. P., Scholl, P. J., Temeyer, K. B. 1990. Shared epitopes between the soluble proteins of Hypoderma lineatum and Hypoderma bovis first instars. J. Parasitol. 76:881-88

173. Pruett, J. H., Temeyer, K. B., Burkctt, B. K. 1988. Antigenicity and immunogenicity of Hypoderma lineatum soluble proteins in the bovine host. Vet. Parasitol. 29:53-63

174. Rastegaev, Y. M. 1972. On parasitism by Hypoderma bovis De Geer of sheep and goats in westem Siberia. Parazytologiya. 6:531-33 (In Russian with English summary)

175. Rich, G. B. 1965. Cattle excitation and insecticide efficiency. Biokemia 7:8-10

176. Rich, G. B. 1965. Systemic treatments for control of cattle grubs Hypoderma spp. in an isolated range herd. Can. J. Anim. Sci. 45:165-72

177. Rich, G. B. 1970. The economics of systemic insecticide treatment for reduction of slaughter trim loss caused by cattle grubs, Hypoderma spp. Can. J. Anim. Sci. 50:301-10

178. Riha, J., Renda, V., Minar, J., Matouskova, O. 1978. The effect of the Hypoderma infestation in cattle on milk production indicators of firstcalvers. Vet. Med. (Prague) 23:597605 (In Czech with English summary)

179. Riley, C. V. 1892. The ox bot in the United States. Insect Life 4:302-17

180. Robertson, R. H. 1978. Potential for vaccines as a protection against cattle grubs. In Research Highlights-1977, pp. 46-47. Lethbridge, Alta.: Agric. Can. Res. Stn.

181. Roubaud, E., Perard, C. 1924. Studies of Hypoderma or cattle grubs; extracts of oestrid larvae and immunization. Bull. Soc. Pathol. Exot. 17:259-72 (In French)

182. Roudabush, R. L. 1936. Arthropod 
and helminth parasites of the American bison (Bison bison). J. Parasitol. 22: 517-18

183. Salt, R. W. 1944. The effects of subzero temperatures on Hypoderma lineatum Devill. Sci. Agric. 25:156-60

184. Schaefer, C. W. 1979. Feeding habits and hosts of calyptrate flies (Diptera: Brachycera: Cyclorrhapha). Entomol. Gen. 5:193-200

185. Scharff, D. K. 1950. Cattle grubs: their biologies, their distribution, and experiments in their control. Mont. State Coll. Agric. Exp. Stn. Bull. 471. $74 \mathrm{pp}$.

186. Scharff, D. K., Sharman, G. A. M., Ludwig, P. 1962. Illness and death in calves induced by treatments with systemic insecticides for the control of cattle grubs. J. Am. Vet. Med. Assoc. 141:582-87

187. Scholl, P. J. 1989. Cattle grub populations show decline. Prime Cuts. Spring, 1989:3

188. Scholl, P. J. 1990. A review of parasites, pathogens, and predators of cattle grubs. Southwest. Entomol. 15: 360-65

189. Scholl, P. J., Colwell, D. D., Weintraub, J., Kunz, S. E. 1986. Area-wide systemic insecticide treatment for control of cattle grubs, Hypoderma spp. (Diptera: Oestridae): two approaches. J. Econ. Entomol. 79:1558-63

190. Scholl, P. J., Guillot, F. S., Wang, G. T. 1992. Moxidectin: systemic activity against common cattle grubs (Hypoderma lineatum) (Diptera: Oestridae) and trichostrongyle nematodes in cattle. Vet. Parasitol. 41: 203-9

191. Scholl, P. J., Hironaka, R., Weintraub, J. 1988. Impact of cattle grub (Hypoderma spp.) (Diptera: Oestridae) infestations on performance of beef cattle. J. Econ. Entomol. 81:246-50

192. Scholl, P. J., Schwinghammer, K. A., Chamberlain, W. F. 1989. Technique for age-grading late third-instar Hypoderma lineatum (Diptera: Oestridae). J. Med. Entomol. 26:230-33

193. Scholl, P. J., Weintraub, J. 1988. Gonotrophic development in Hypoderma lineatum and $H$. bovis (Diptera: Oestridae), with notes on reproductive capacity. Ann. Entomol. Soc. Am. 81: 315-24

194. Scholl, P. J., Weintraub, J., Khan, M. A. 1985. Late-season treatment of cattle for control of warble grubs. In Research Highlights-1984, ed. L. J. L. Sears, E. E. Swierstra, pp. 29-30.
Lethbridge, Alta.: Agric. Can. Res. Stn.

195. Schwinghammer, K. A., Pruett, J. H., Temeyer, K. B. 1988. Biochemical and immunochemical properties of HPLC peak 2, an ion-exchange fraction of common cattle grub (Diptera: Oestridae). J. Econ. Entomol. 81:549-54

196. Scott, H. G. 1964. Human myiasis in North America (1952-1962 inclusive). Fla. Entomol. 47:255-61

197. Sergent, E., Sergent, E. 1950. Etudes sur le varron du boef en Algerie: essais de traitement et de vaccination. Inst. Pasteur Alger. Arch. 28:255-322

198. Simco, J. S., Lancaster, J. L. 1964. Effects of soil type, moisture level, and temperature on larval and pupal stages of the common cattle grub, Hypoderma lineatum. J. Kans. Entomol: Soc. 37:11-20

199. Simmons, S. W. 1937. Some histopathological changes caused by $\mathrm{Hypo-}$ derma larvae in the esophagus of cattle. J. Parasitol. 23:376-81

200. Simmons, S. W. 1939. Digestive enzymes of the larva of the cattle grub Hypoderma lineatum (De Villers). Ann. Entomol. Soc. Am. 32:621-27

201. Simmons, S. W. 1939. Some histopathological changes in the skin of cattle infected with larvae of Hypoderma lineatum. J. Am. Vet. Med. Assoc. 95:283-88

202. Singh, A., Chhabra, R. C. 1973. Incidence of arthropod pests of domesticated animals and birds. Ind. J. Anim. Sci. 43:393-97

203. Soran7o, L. 1980. Development of the oenocytes of the cattle grub during the course of the three larval instars (Diptera-Oestridae). Ann. Sci. Nat. Zool. Biol. Anim. 2:35-50 (In French with English summary)

204. Tagle, V. I. 1959. Primer caso autoctono de hipodermosis en Chile. Bol. Chil. Parasitol. 14:15-17

205. Tarry, D. W. 1983. The eradication of cattle warble flies in Britain. Antenna 7:17-20

206. Tarry, D. W. 1984. Progress of the warble fly eradication scheme in Great Britain. See Ref. 31, pp. 73-77

207. Tarry, D. W. 1989. Warble flies are on their last legs. Farmers Wkly. 111:71

208. Temeyer, K. B., Pruett, J. H. 1990. Preparation of biologically active messenger RNA from larvae of the common cattle grub (Diptera: Oestridae). Ann. Entomol. Soc. Am. 83:55-58

209. Terada, B., Ono, S. 1930. The toxicological investigation in the toxic substance obtained from the larvae of 
Hypoderma sp. of Mongolian cattle at the oesophageal stage. J. Jpn. Soc. Vet. Sci. 9:212-20. (In Japanese with English summary)

210. Thornberry, H. 1984. Experiences in the control of Hypoderma bovis and Hypoderma lineatum in the Republic of Ireland. See Ref. 31, pp. 79-88

211. Tong, N. T., Imhoff, J. M., Lecroisey, A., Keil, B. 1981. Hypodernin A, a trypsin-like neutral proteinase from the insect Hypoderma lineatum. Biochem. Biophys. Acta 658:209-19

212. Wall, R., Strong, L. 1987. Environmental consequences of treating cattle with the antiparasitic drug ivernectin. Nature 37:418-21

213. Weintraub, J. 1961. Inducing mating and oviposition of the warble flies Hypoderma bovis (L.) and $H$. lineatum (De Vill:)(Diptera: Oestridae) in captivity. Can. Entomol. 93:149-56

214. Weintraub, J. 1978. Pilot test of sterile insect releases for warble fly control. In Research Highlights-1977, pp. 4853. Lethbridge, Alta.: Agric. Can. Res. Stn.

215. Weintraub, J., McGregor, W. S., Brundrett, H. M. 1961. Artificial infestations of the northern cattle grub, Hypoderma bovis, in Texas. J. Econ. Entomol. 54:84-87

216. Weintraub, J., Robertson, R. H., Gooding, R. H. 1968. Experiments in hybridizing the warble flies Hypoderma lineatum (de Villers) and $H$. bovis
(Linnaeus) (Diptera: Oestridae). Can. J. Zool. 46:129-33

217. Weintraub, J., Scholl, P. J. 1984. The joint Canada-U.S.A. pilot project on warble grub control. In Research Highlights-1983, pp. 30-32. Lethbridge, Alta.: Agric. Can. Res. Stn.

218. Whitten, L. K. 1970. The control of external parasites of cattle. N.Z. Vet. J. 18:146-47

219. Wilson, G. W. C. 1986. Control of warble fly in Great Britain and the European community. Vet. Rec. 118: 653-56

220. Wolfe, L. S. 1959. Observations on the histopathological changes caused by the larvae of Hypoderma bovis (L.) and Hypoderma lineatum (De Vill.) (Diptera: Oestridae) in tissues of cattle. Can. J. Anim. Sci. 39:145-57

221. Wood, D. M. 1987. Oestridae. In Nearctic Diptera, Vol. II. Monograph 28, ed. J. F. McAlpine, pp. 1147-58. Ottawa: Res. Branch, Agric. Can.

222. Worden, A. N. 1952. The warble fly and other problems of hide improvement. Vet. Rec. 64:720-21

222a. Wright, A. I. 1979. Warble fly eradication. Vet. Annu. 19:54-60

223. Zottner, G., Coste, E. 1939. The complete development of Hypoderma bovis in a horse. C. R. Soc. Biol. 131:907-8 (In French)

224. Zumpt, F. 1965. In Myiasis in Man and Animals in the Old World, pp. 217-29. London: Butterworths. 267 pp. 